\title{
Value Relevance Of Institutional Investors
}

\author{
George Karathanassis \\ Department of Business Administration, \\ Athens University of Economics and Business \\ Nikolaos Philippas \\ Department of Financial and Banking Management, \\ University of Piraeus \\ Efthymios G. Tsionas \\ Department of Economics, \\ Athens University of Economics and Business \\ and Demosthenes Hevas \\ Department of Business Administration, \\ Athens University of Economics and Business
}

\begin{abstract}
In this paper we investigate the influence of institutional investors on share prices using data from companies quoted on the Athens Stock Exchange. For finance theorists the value of an investment, real or financial, is a function of its expected benefits and the riskiness of these benefits. Whatever influences are exerted by the structure of equity ownership are diversified away by efficient risk-averse investors. Managerial and agency theorists argue that the particular ownership structure may have an effect on share value or returns. Their arguments are based (mainly) on the consequences of the separation of ownership from control. In addition to traditional methods of estimation we have used Chamberlain's (1982) multivariate panel data estimator, which allows for arbitrary patterns of error autocorrelation and parameter temporal behavior. Among all alternative methods of estimation used, only this one produced a statistically significant and econometrically well specified relationship between share prices and institutional shareholdings.
\end{abstract}

\section{Introduction}

Researchers wishing to determine the extent to which stock price market behavior can be explained by theoretical valuation constructs have tested a number of empirical valuation models ${ }^{1}$. All extant empirical valuation mod- 
els implicitly assume that equity ownership structures are value irrelevant. More specifically the distribution of shares among managers, individual shareholders, institutions, block-holders and others does not exert any appreciable influence on share prices. Yet a number of influential theoretical works conclude that the structure of equity ownership may be a variable with value relevance within the framework of an empirical valuation model ${ }^{2}$. In this paper we investigate the value relevance of ownership distribution on share prices with data from the Athens Stock Exchange using panel data analysis an approach virtually ignored in the area of finance.

Previous studies use cross sectional analysis of US (mainly) and UK data. Cross sectional analysis cannot capture such dynamic relationships as changes in share ownership structure. Use of panel data is very important in capturing changes in ownership over time. Further the potential influence of ownership structure on various measures of performance has been studied in the absence of the effect exerted upon share prices and other measures of performance of other important valuation variables. In this paper we have attempted to address some of the issues, largely ignored by previous works, via (i) panel data analysis, (ii) explicit share valuation models, and (iii) appropriate estimation techniques.

In addition, we depart from all past papers in that we used Chamberlain's (1982) multivariate panel data method. This estimator allows one to have arbitrary error autocorrelation, and parameter temporal behavior. Contrary to previous studies using panel data, this estimator is significantly less restrictive. Existing implementations of panel estimators rely on the unrealistic assumption that parameters are the same over time, and there is no autocorrelation in the residuals, or that autocorrelation is of special form. It turns out that careful specification tests reveal the inadequacies of standard fixed or random effect estimators, and the superiority of the multivariate panel data method. Finally, it should be stressed that among all alternative methods of estimation used, only this one produced a statistically significant and econometrically well specified relationship between share prices and institutional shareholdings.

The remainder of this paper is structured as follows. In section 2 we briefly review the theoretical and empirical relationships between share prices and the structure of stock ownership. In section 3 we set out the economic model to be tested, while section 4 is devoted to the development of the appropriate statistical models. In section 5 we present and interpret the empirical findings while section 6 concludes the paper. 


\section{Theoretical constructs \\ 2.1 Efficient pricing of shares}

Within an efficient markets framework share prices are a function of the risk adjusted benefits expected from shares. Shares are priced according to the expected benefits and systematic risks. Influences such as those that might be caused by the particular ownership structure of a company can be thought of as belonging to the specific risk category and as such are diversified away within the CAMP framework. Under this pricing regime the presence of institutional holdings and/or blockholders is value irrelevant. All shareholders (both, inside and outside) are value maximisers and homogeneous.

\subsection{Managerial and Agency Theories}

The separation of ownership from control has given rise to the development of managerial ${ }^{3}$ and agency ${ }^{4}$ theories. In the modern corporation the separation of ownership from control may lead to a divergence of interests between managers and shareholders. Proponents of managerial theories argue that managers use firm resources to operate the firm in their own interests. Management controlled firms are more likely to adopt non-wealth maximizing policies than owner controlled firms. Agency theorists distinguish between inside shareholders who manage the firm and outside shareholders. Managers who do not own shares tend to act in their own interests adopting investment and financing policies beneficial to them and not necessarily to the company shareholders. However, as management equity ownership increases management and outside shareholders interests coincide. The central idea of these studies is that the modern corporation may be viewed as a coalition of various groups (managers, individual, shareholders, trade unions, pension funds, mutual funds, debtholders etc.). Each group in order to protect its own interests monitors the management of the firm. The managers are viewed as a separate group with different interests from the other groups in the coalition. For example debtholders may opt for the acceptance of less risky investment projects, shareholders may press for long term performance, mutual funds may be interested in short term results while managers may be interested in the maximization of the growth of the firm. The net outcome of these conflicting interests will depend on the strength of the objectives of each group and the financial capacity to undertake the significant agency costs involved in pursuing this endeavor. This line of reasoning suggests that the issue as to the direction of the relationship between ownership structure and share prices can not be settled ex-ante but is essentially an empirical issue. Ex-ante we could not be certain as to whether management controlled 
firms are more value relevant than owner controlled firms ${ }^{5}$. Against this we should cite the argument that competition in the managerial labor market and the presence on the board of outside shareholders would limit management discretionary powers ${ }^{6}$.

\subsection{Institutional Investors and Blockholders}

Should we expect institutional investors and blockholders to be:

short-term speculators; or

long-term wealth maximizing investors ;

The first type of behavior stems from the fact that fund managers, in particular, are themselves constantly being appraised for good quarterly/yearly performance ${ }^{7}$.

When institutional investors hold large amounts of shares of a firm, short-term reductions in earnings per share may cause them to sell their shares lest they become locked into a losing stock. These transactions will cause a decline in the price of the stock possibly leading up to a hostile takeover bid. In an effort to reduce the probability of a takeover bid top managers may invest less in R \& D projects, market development projects, management development programs and other long-term projects. This line of thought would predict a negative association between share prices and institutional holdings. This kind of behavior may further be reinforced by the fact that a significant proportion of shares exposes the fund to a high degree of specific risk. This perspective points to a negative association between share prices and the presence of institutional shareholders.

\subsection{Efficient Monitoring Hypothesis}

According to this hypothesis ${ }^{8}$ institutional investors and large blockholders, unlike small individual shareholders, find it cost effective to monitor management behavior. The monitoring process of management actions compels the high echelon of management hierarchy into adopting value maximizing policies. According to this hypothesis we would expect no significant association between share prices and the presence of institutional investors and large blockholders. What we have therefore are various conflicting views and hypotheses regarding the effect of stock ownership on share prices. 


\subsection{Earlier Results}

Many researchers have sought to shed light on the issues stated above. Their results are just as conflicting as are the competitive hypotheses they sought to investigate.

Regarding the issue of ownership controlled firms Short and Keasey (1997) found no influence on the company. Similar conclusions were reached by Holderness and Sheehan (1988). Leech and Leahy (1991) reported opposite results in that ownership controlled firms were associated with higher valuation ratios whereas Thonet and Pensgen (1979) found that management controlled firms were associated with higher market values but that owner controlled firms had higher growth in total assets.

There was no significant association between corporate value and blockholders as found by Hermalin and Weisbach (1988) Murali and Welch (1989) as found by Morck et al (1988). The issue of the effect of institutional holdings on firm performance did, (empirically), not fare any better. Whereas Pound (1988) and Graves (1988) report negative associations between value and institutional holdings and R and D and the size of institutional ownership respectively, Hansen and Hill (1991) found a positive association between R \& D and institutional holdings. Two more studies found a positive association between value/return and the proportion of shares held by institutional investors. McConnell and Servaes (1990) and Chagnanti and Damanpour (1991).

As with all firm performance studies the results are mixed. Since the issues examined empirically have important implications for portfolio management and market efficiency, new and possibly more efficient examination procedures are called forth. For it is only through repeated testing with data from different market structures (and cultures) and different degrees of economic development that new knowledge may be derived.

\subsection{Research Objectives}

The present paper investigates the relationship between share prices and equity ownership of companies quoted on the Athens Stock Exchange (ASE). In this paper unlike others, we use panel data analysis and apply appropriate statistical techniques to measure empirical relationships. As we argue in section 4 panel data has a number of advantages over both cross section and time series data and allows us to obtain efficient and consistent estimates.

Our research hypothesis is based upon the theoretical valuation models and managerial/organizational perspectives surveyed in section 2 of this paper. Our basic empirical valuation model rests on the theoretical framework 
developed by Ohlson $(1989,1995)$ which is equivalent, to the dividend valuation model developed by Miller and Modigliani (1961).

\section{Share valuation models}

\subsection{The Economic Model}

According to Ohlson (1989, 1995), under clean surplus accounting and assuming that the time series behavior of abnormal accounting earnings satisfies a certain stochastic process, a firm's market value is determined as follows:

$$
\mathrm{MV}_{\mathrm{t}}=\mu \mathrm{A}_{\mathrm{t}}^{\mathrm{a}}+v \mathrm{EQ}_{\mathrm{t}}+\varphi\left[V_{t}\right]
$$

where:

$\mathrm{MV}_{\mathrm{t}}$ : is the market value of the equity for period $t$;

$\mathrm{A}_{\mathrm{t}}^{\mathrm{a}}$ : $\quad$ are the abnormal accounting earnings for period $\mathrm{t}$;

$\mathrm{EQ}_{\mathrm{t}}$ : is the book value of equity for period $\mathrm{t}$;

$\left[V_{t}\right]$ : is a vector that contains all other non- accounting value relevant variables not yet affecting $\mathrm{A}^{\alpha}{ }_{\mathrm{t}}$ and $\mathrm{EQ}_{\mathrm{t}}$.

For the purposes of our analysis, we will assume that the ownership variables are included in the $\left[V_{t}\right]$ and consequently we will be testing the following version of Ohlson's model:

$\mathrm{P}_{\mathrm{t}}=\mathrm{a}_{0}+\mathrm{a}_{1} \mathrm{~A}_{\mathrm{t}}^{\mathrm{a}}+\mathrm{a}_{2} \mathrm{EQ}_{\mathrm{t}}+\mathrm{a}_{3} \mathrm{PO}_{\mathrm{t}}$

where :

$\mathrm{P}_{\mathrm{t}}: \quad$ is the common share price;

$\mathrm{A}_{\mathrm{t}}^{\mathrm{a}}$ : the abnormal earnings per share for period $\mathrm{t}$;

$A_{t}: \quad$ the accounting earnings per share for period $t$;

$E Q_{t}$ : the book value of equity per share at the end of period $t$;

$\mathrm{R}_{\mathrm{f}}$ : $\quad$ the risk free rate of return at the beginning of period $t$;

$\mathrm{PO}_{\mathrm{t}}$ : the percentage of shares held by investment trusts and mutual funds at the end of period $t$;

\subsection{Expected signs of the relationships}

On the basis of the above analysis and in conjunction with the discussion of the theoretical constructs of the managerial/agency theories we expect the following relationships between the variables included in the economic model: 
1. $\frac{d P}{d A^{\alpha}}>0$. i.e. The greater the abnormal earnings per share the greater the price of a share.

2. $\frac{d P}{d E Q}>0$ i.e. The greater the book value of equity per share, the greater the price of a share.

3a. $\frac{d P}{d P O}=0$ Changes in the proportion of equity held by institutional investors have no effect on the price of a share. Apparently the market prices shares efficiently.

3b. $\frac{d P}{d P O}<0$. Changes in the proportion of the equity held by institutional investors have a negative effect on share prices. In this case institutional investors are short-term traders causing management to adopt suboptimal policies.

3c. $\frac{d P}{d P O}>0$. Changes in the proportion of the equity held by institutional investors constitute a factor of value.

Thus, our approach specifies a certain number of variables as being important determinants of share valuation and in addition it specifies the sign of relationships that share prices may be expected to bear towards the variables affecting them.

We have, therefore, a testable hypothesis and only by resorting to empirical testing will we be able to measure the response coefficients in question.

\section{The sample}

\subsection{Sample Description and Data Sources}

The sample includes 59 firms listed on the Athens Stock Exchange for which all relevant ownership information were available for a six year period from 1991 to 1996 inclusive. Accounting and stock market data were taken from the Athens Stock Exchange database, the portfolios of the mutual funds and investment companies were constructed from primary data provided to us by institutional investors. Finally, the risk free rate was obtained from publications of the Bank of Greece. 


\subsection{Definition of Variables}

For the purpose of testing empirically the model described by equation (2) the dependent and independent variables included are defined as follows:

$\mathrm{P}_{\mathrm{t}}$ : is the common stock price six months after the end of fiscal year $\mathrm{t}$ :

$A_{t}: \quad$ is the accounting earnings per share for period $t$.

$\mathrm{A}_{\mathrm{t}}^{\mathrm{a}}$ : $\quad$ represents abnormal earnings per share for period $\mathrm{t}$, that is $A_{t}{ }^{a}=A_{t}-R_{f} E Q_{t-1}$. $A_{t}^{a}$ could alternatively be defined as pure profits, it being the difference between earnings per share $\left(\mathrm{A}_{\mathrm{t}}\right)$ minus the opportunity cost of these earnings $\left(\mathrm{R}_{\mathrm{f}} \mathrm{EQ}_{\mathrm{t}-1}\right)$, according to Ohlson $(1989,1995)$ and Feltham and Ohlson (1995) contributions.

$E Q_{t}$ : represents the book value of equity per share for period $t$.

$\mathrm{R}_{\mathrm{t}}$ : is the annual rate of return on one-year government bills at the beginning of period $t$.

$\mathrm{PO}_{\mathrm{t}}$ : represents the percentage of shares held by investment trusts and mutual funds at the end of period $t$.

\section{Econometric models}

Researchers testing economic relationships analyse, as a rule, time series or cross section data. The main advantage of using time-series analysis is that it enables one to discover dynamic forces affecting the dependent variable in question. The main disadvantage is that time-series data may pose autocorrelation and multicollinearity problems. On the other hand, cross-section data may not pose serious problems of autocorrelation and multicollinearity but suffer from problems of heteroscedasticity and may not enable the researcher to detect dynamic forces, which may affect the dependent variable.

Algebraically the relationship can be represented as follows:

$$
\begin{gathered}
Y_{i t}=\mu_{i}+\lambda_{t}+\sum_{k=1}^{K} \beta_{k} X_{k i t}+\varepsilon_{i t} \quad \mathrm{i}=1, \ldots, \mathrm{N} \\
\mathrm{t}=1, \ldots, \mathrm{T}
\end{gathered}
$$

where $Y_{\text {it }}$ represents the value of the dependent variable for cross-section $\mathrm{i}$ at time $\mathrm{t}, \mathrm{X}_{\mathrm{kit}}$ is the value of the $\mathrm{k} t \mathrm{~h}$ explanatory variable for cross-section $\mathrm{i}$ at time $t, \mu_{\mathrm{i}}$ is an unobserved cross-section effect, $\lambda_{\mathrm{t}}$ is an unobserved time effect and $\varepsilon_{i t}$ is the unobserved overall remainder. The above relationship may be estimated by making two assumptions; firstly that the $\mu_{\mathrm{i}}$ and $\lambda_{\mathrm{t}}$ are fixed parameters and secondly that they are random. The first assumption 
leads to the dummy variable model ${ }^{9}$ while the second leads to the error components model ${ }^{10}$.

The estimation of the coefficients involves the use of a modified Aitken procedure consisting of two stages. In the first stage the estimate of the variance of the error components were obtained using least squares with dummy variables residuals, a method proposed by Amemiya (1971), while in the second stage use is made of the familiar generalized least squares estimator:

One problem with the fixed-effects or random-effects formulations is that although the intercept $\beta_{1 \text { it }}$ is assumed to vary over individuals and/or time, a parameter constancy assumption is made regarding the remaining parameters. This is usual practice in applied econometrics.

The SUR model applied to panel data was proposed by Chamberlain (1982), and does not make restrictive assumptions about the autocorrelation of error terms, since it accommodates arbitrary patterns of autocorrelation. It also does not make restrictive assumptions about inter-temporal parameter stability as all parameters (or, of course, subsets of the parameter vector) can be time varying without restrictions on the pattern of inter-temporal variation. Moreover, likelihood ratio tests can be devised in a straightforward manner to test that certain parameters are constant over time, and / or serial correlation is absent. All these features are quite important over the more restrictive fixed- or random-effect treatments.

Formally, the specification is given by the following:

$$
\mathrm{Y}_{\mathrm{it}}=\sum_{k=1}^{K} \beta_{\mathrm{kt}} \cdot \mathrm{X}_{\mathrm{kit}}+\varepsilon_{\mathrm{it}}
$$

to capture the idea that model parameters vary over time.

Writing (8) as

$$
\underset{(1 x 1)}{\mathrm{Y}_{\mathrm{it}}}=\underset{(1 x k)}{\mathrm{X}_{\mathrm{it}}^{\prime}} \cdot \underset{(k x 1)}{\beta_{\mathrm{t}}}+\varepsilon_{\mathrm{it}}
$$

where $\mathrm{X}_{i t}^{\prime}=\left[\begin{array}{llll}\mathrm{X}_{1 \mathrm{it}} & \mathrm{X}_{2 \mathrm{it}} \ldots \mathrm{X}_{\mathrm{kit}}\end{array}\right]$, and stacking all cross-section observations for a given time period, we obtain:

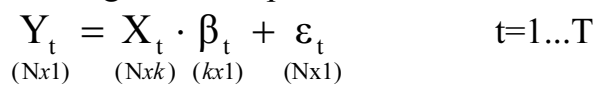

This model can be estimated using SUR. For purposes of estimation, the SHAZAM computer program has been used. Notice that the standard assumption in SUR estimation is $\varepsilon_{t} \sim N(0, \Sigma)$. In this case, the covariance matrix $\Sigma$ measures the correlations of $\varepsilon_{t}$ 's implying that no prior restrictions are placed on the autocorrelation of error terms. Similarly, by estimating different $\beta_{\mathrm{t}}$ 's no restrictions are placed on the temporal behavior of regression parameters. 


\section{Empirical findings \\ 6.1 Diagnostic Tests For O.L.S.}

As an initial step we present results of a number of diagnostic tests for Ordinary Least Shares (O.L.S.) (TABLE-1-). As can be seen from table 1, O.L.S. estimates seem to be associated with several problems such as: (i) non-normality in the equations for 1993-96, based on results of the JarqueBera test, (ii) heteroscedasticity for 1991 and 1993 (Breusch -Pagan and Glejser tests), (iii) functional form misspecification for 1991,1992 and 1996 (Ramsey test), and (iv) cross-section parameter instability as evidenced by the Chow break-point test. For these tests, see Greene (1997).

Although (ii) could be attributed to (i) and (iii) to (iv) the fact that test statistics reject so often the null hypothesis implies that O.L.S. estimates are unsatisfactory. For this reason we have decided to use random- effect model (RE) and SUR estimation in order to obtain better estimates. We consider it very important that the RESET test rejects the null hypothesis of correct functional specification. This finding accords well with findings reported in McConnell and Servaes (1990) and Morck, Schleifer and Vishny (1988) according to which the relationship should be curvilinear.

\subsection{Diagnostic Tests For Alternative Estimating Techniques}

Next we performed diagnostic tests for alternative estimating techniques (TABLE-2-).

The most interesting finding in table 2 is the statistically significant Ramsey misspecification tests for POLS (Pooling Least Squares), LSDV (Least Squares with Dummy Variables), and RE (Random Effect) equations, for 1991,1992 and 1996. On the other hand, SUR estimation seems to be free from Ramsey- type functional form misspecification. Corroborating evidence is provided by the sequential break-point Chow (1960) test which indicates parameter instability for 1991 and 1992 for all estimating methods except SUR. We take this as evidence in favor of SUR and against POLS, LSDV and RE estimators. Since the RESET test is quite general (the alternative hypothesis includes a variety of possible nonlinear models) we take this as evidence that POLS, LSDV, and RE are not correctly specified as one would expect from the evidence in McConnell and Servaes (1990) and Morck, Schleifer and Vishny (1988). However, the SUR model does not suffer from functional form misspecification problems implying that we need not worry about a possibly curvilinear or more generally about a nonlinear relationship.

Turning now to heteroscedasticity, we have conflicting results: Although Harvey's $X_{(3)}^{2}$ statistic finds no evidence in favor of heteroscedasticity, the 
Breusch and Pagan $X_{(3)}^{2}$ statistic supports heteroscedasticity for 1991 and 1993 in connection with POLS,LSDV and RE (but not SUR). The conflict among the tests may be resolved by noting that heteroscedasticity could be of the form $\hat{u}_{t}^{2}=X_{t}{ }^{\prime} \gamma+u_{t}$ rather than $\log \hat{u}_{t}^{2}=X_{t}{ }^{\prime} \gamma+u_{t}$. It is, however, interesting that neither the Breusch and Pagan nor the Harvey tests reject heteroscedasticity for the SUR equations.

Non-normality is a common problem across estimating techniques. However, the Jarque and Bera $\mathrm{X}_{(2)}^{2}$ test, although significant, is significantly lower, across years, compared to the values of the Jarque-Bera statistic for POLS,LSDV and RE.

Overall, it appears that functional form misspecification, heteroscedasticity, non-normality and parameter instability problems either completely disappear or become considerably less important when SUR is used. Based on this evidence we may conclude that SUR appears to be superior in terms of specification.

\subsection{Empirical Results}

Empirical results are reported in table 3. For POLS, LSDV, RE the coefficients are assumed time-invariant and the relevant parameter estimates as well as t-statistics are reported in the column with the heading "1991".

The last column (with heading "pooling /SUR") reports results for the SUR model assuming all coefficients are time invariant. It has been shown in connection with likelihood ratio tests that this model can be rejected in favor of a SUR model with all parameters being time-varying (with the exception of PO). Results for this model are reported in the row headed "SUR".

(i) Coefficients of $\mathrm{A}^{\mathrm{a}}$

Our results are in accordance with our a priori expectations. Parameters corresponding to $\mathrm{A}^{\mathrm{a}}$ are generally positive, ranging from 1.97(LSDV) to 3.84 (POLS), and they are highly statistically significant. SUR results show that this parameter shows high dynamic variation, ranging from 0.78 (1995) to 2.85 (1991). It is interesting that t-statistics drop from an average of 6.0 for the period 1991-1993 to about 2.0 for the 1995-96 period.

\section{(ii) Coefficients of EQ}

In general this finding accords with the sign of our economic relationship. These coefficients are positive and (with the exception of LSDV) statistically significant. According to "SUR" there exists a clear downward trend with an accompanying reduction in t-statistics. It is interesting that according to pooled OLS and SUR, estimates are greater than one. According to LSDV,RE and pooled/SUR the coefficients are less than one. 


\section{(iii) Coefficients of PO}

It may be recalled that we had identified three alternative perspectives pointing to a different relationship between share prices and the size of institutional holdings. PO seems to have a positive effect only according to pooled OLS. All other estimating techniques agree that this effect is negative. Both LSDV and RE imply that this effect is statistically insignificant. SUR (and pooling/SUR to lesser extent) on the other hand, imply a statistically significant effect. The relevant estimates are $-1437.9(-2.51)$ for SUR and $-1131.5(-1.98)$ for pooling/SUR. Of course, the negative contribution of PO implies that institutional investors are short-term traders, see (3b) in section 3.2 .

We attribute this difference to the much satisfactory behavior of SUR in terms of values of the diagnostic statistics. Although in general, pooled OLS seems to give the lowest standard errors, the assumption that coefficients are time invariant is at odds with the data (see diagnostics in table 1). Utilizing this information is crucial in dealing with the misspecification problems implied by the constant coefficient assumptions. The gain materializes in much lower standard errors for EQ and PO.

The finding that the coefficient of PO is very close to statistical significance in pooling/SURE should not escape our attention. In this model, coefficients are also time invariant (as in POLS, LSDV, and SUR). This does not constitute a contradiction because (contrary to all other estimating techniques) both SUR and pooled SUR deal non-parametrically with the problem of auto-correlation (via the $\Sigma$ matrix). This gives pooled SUR a t-statistic of -1.98 for PO, compared to 0.36 for POLS, -0.32 for RE and 1.62 for LSDV. The additional feature of SUR (abolition of parameter constancy assumption) further raises the t-statistic to -2.51 and moves the estimate downwards to 1437.9 (compared to -1131.5 for pooled SUR, -213.9 for RE, -1024.0 for LSDV and 262.8 for pooled OLS).

It may be noted that further support for the SUR model is provided by values of the $R^{2}$ statistic. This statistic is 0.936 for SUR, compared to 0.580 for POLS, 0.836 for LSDV 0.799 for RE and 0.737 for pooled SUR. Relying on our SUR results we could conclude that institutional investors appear to be short-term traders influencing negatively share prices.

\section{Conclusions}

We set out to investigate whether institutional holdings exert an independent influence on share prices. We used data from companies quoted on the Athens Stock Exchange, a market which, for some, is considered to be emerging whereas, for others, is already considered to be a developed stock market. 
As to our main variable of interest, PO, we should stress the following. Based on LSDV and/or RE estimation this variable is value irrelevant that is insignificant. On the other hand, SUR estimation provides a statistically significant (as well as econometrically well specified) negative relationship. This result may be attributed to the restrictive assumptions about parameter temporal behavior made by LSDV and RE. Since SUR allows for an arbitrary pattern and seems to be free of functional misspecification problems the results obtained by SUR are more reliable.

Chamberlain's (1982) multivariate approach to estimating the economic relationships seems to be justified on empirical grounds. Among all alternative methods of estimation, only this method produced results in accordance with our expectations. Overall we could, therefore, argue that institutional investors appear to be investing for short periods of time, moving in and out of shares according to short-term results. This speculative behavior may compel management to cancel long-term financial policies resulting thus in future lower prices.

\section{Notes}

1. A large number of papers have been written on the subject matter of empirical valuation models see for instance Keenan (1970) and Karathanassis and Philippas (1988)

2. For an excellent review and critical appraisal of the relevant literature see Short (1994)

3. Williamson (1964).

4. Marris (1964). "The Economic Theory of Managerial Capitalism" MacMillan

5. Jensen and Meckling (1976)

6. Fama (1980) Demsetz (1983)

7. Drucker (1987).

8. Pound (1988)

9. The well known covariance analysis, which in the past had been used extensively in the area of production function. See Mundlak (1963) and Hock (1962).

10. Wallace and Hussain (1969)

11. Mundlak (1978) and Hausman and Taylor (1981)

12. For a number of variations of the error components model see Baltagi (1995).

13. Standard LR tests of parameter constancy indicate that all parameters (except the coefficient of PO) are time variant. Detailed tests are available upon request. 


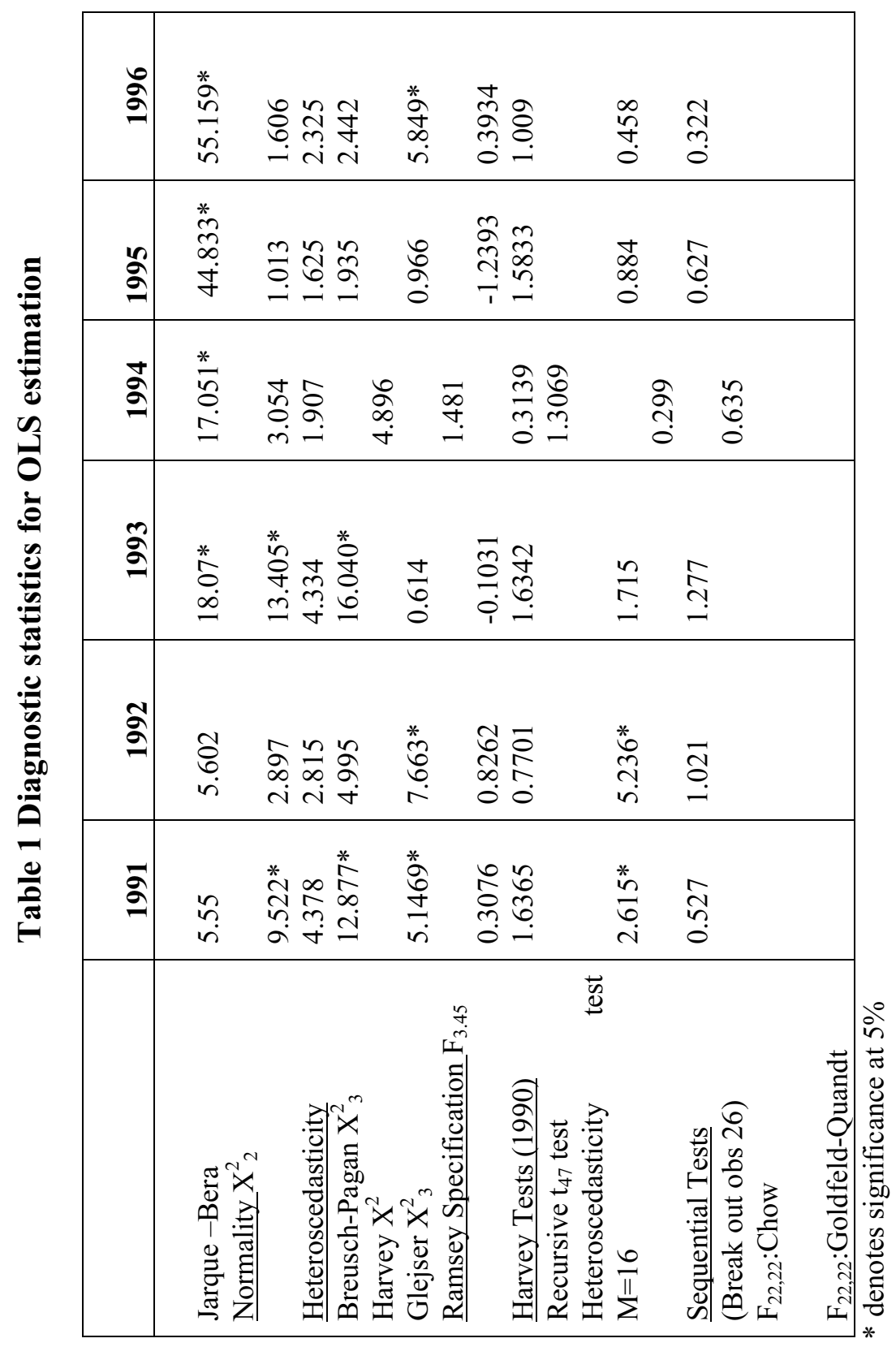




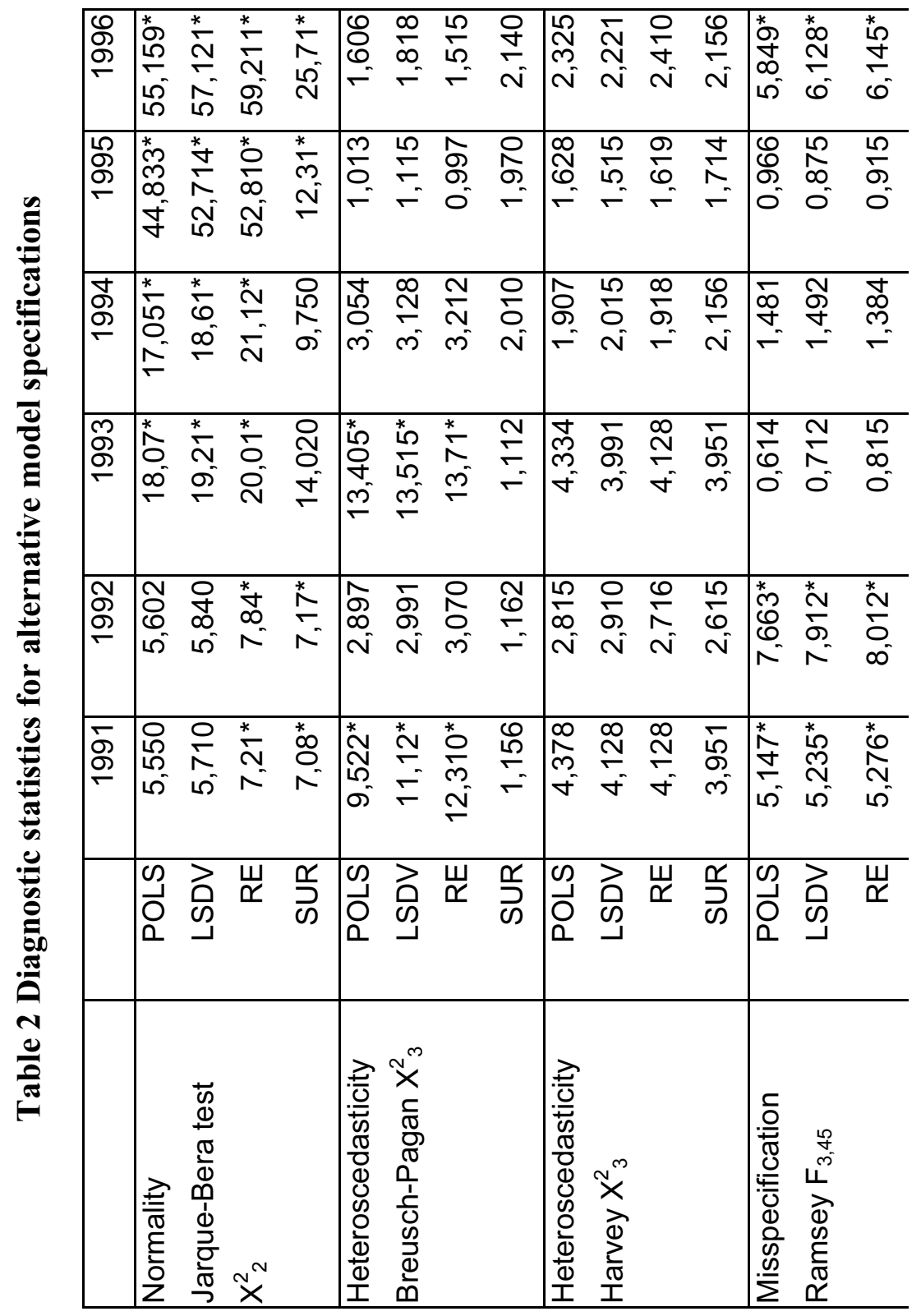




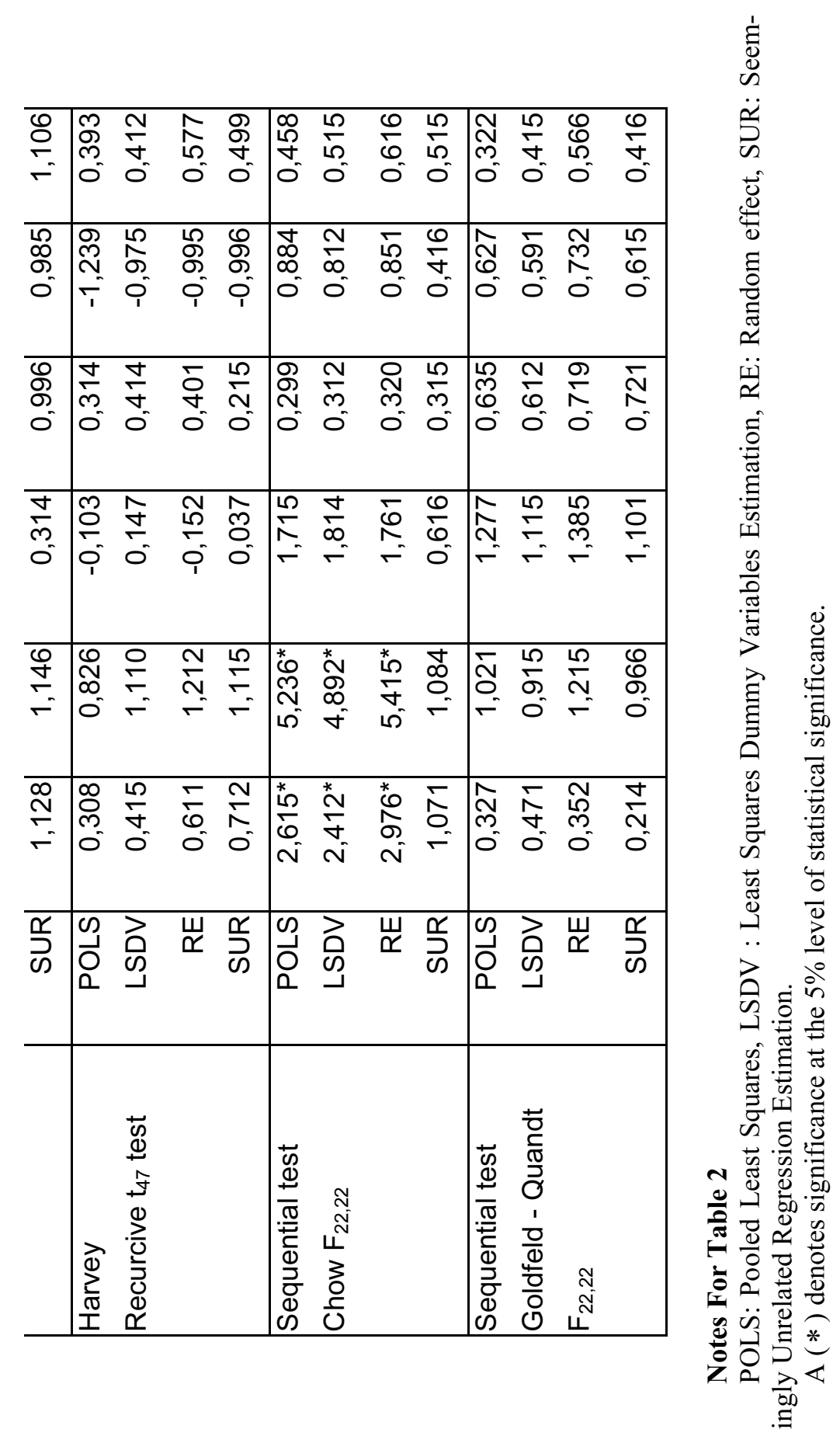




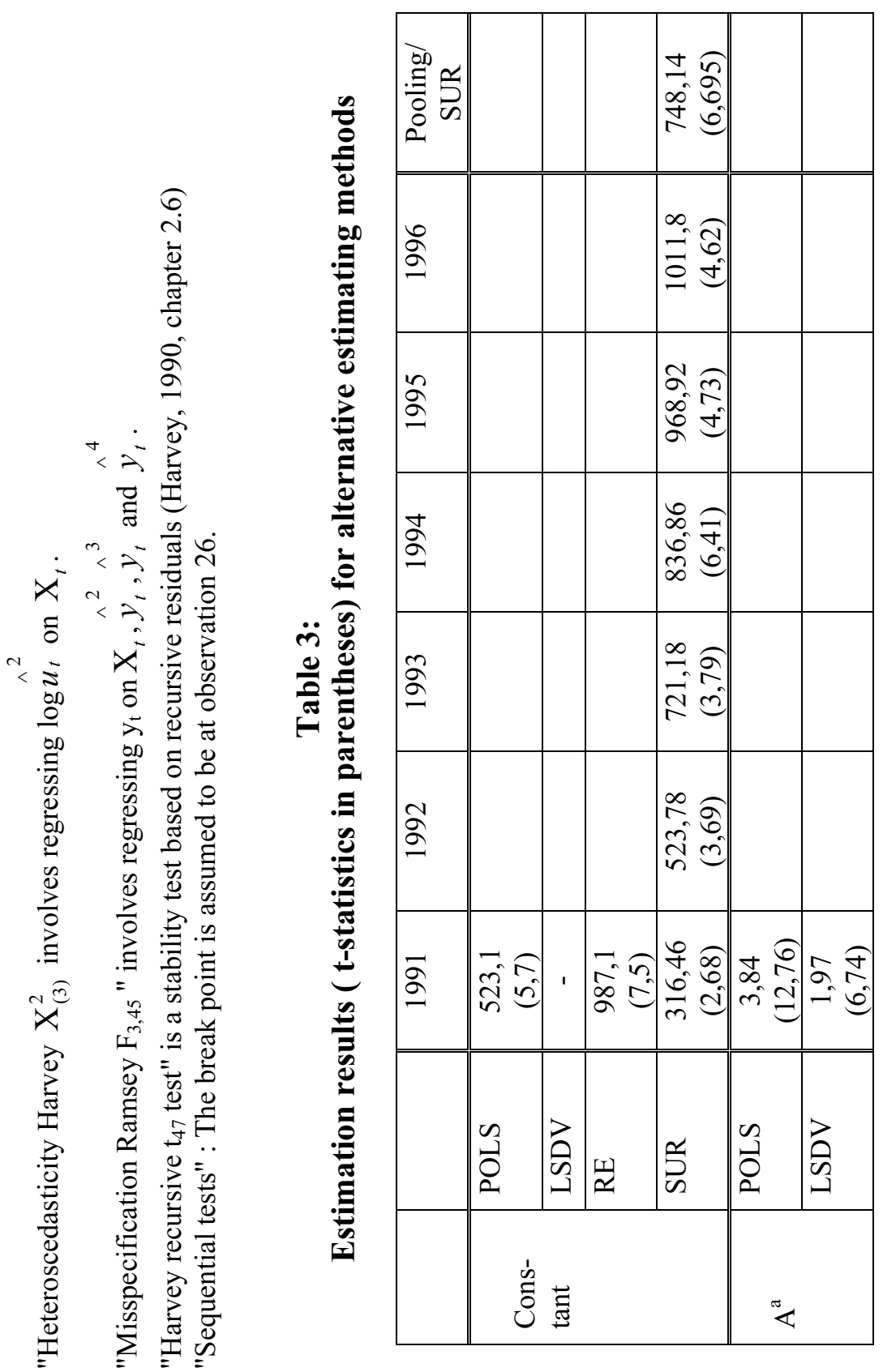




\begin{tabular}{|c|c|c|c|c|c|c|c|c|c|c|c|}
\hline & 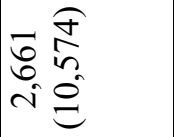 & & & & $\begin{array}{cc}a & \widehat{\sigma} \\
\hat{\infty} & \hat{\alpha} \\
0 & \hat{a}\end{array}$ & & & & 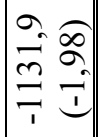 & & \\
\hline & 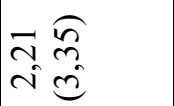 & & & & $\mid \begin{array}{cc}1 & 6 \\
n & 0 \\
2 & 0 \\
0 & 0 \\
0\end{array}$ & & & & & & \\
\hline & $\begin{array}{l}\infty \approx \\
\hat{0} \\
0\end{array}$ & & & & $\begin{array}{ll}\bar{n} & \hat{a} \\
\tilde{0} & 0\end{array}$ & & & & & & \\
\hline & $\begin{array}{l}\hat{n} \\
\text { N } \\
\text { N }\end{array}$ & & & & $\left|\begin{array}{ll}n & 0 \\
\infty & + \\
0 & \infty\end{array}\right|$ & & & & & & \\
\hline & $\begin{array}{l}\hat{0} \\
\infty \\
-\infty \\
0\end{array}$ & & & & $\begin{array}{l}= \\
= \\
=0 \\
=\end{array}$ & & & & & & \\
\hline & $\begin{array}{l}n \widehat{\hat{a}} \\
\text { vE }\end{array}$ & & & & $\begin{array}{ll}0 & 0 \\
= & = \\
-\infty\end{array}$ & & & & & & \\
\hline $\begin{array}{ll}0 & \widehat{\sigma} \\
n & 0 \\
\sim & 0\end{array}$ & 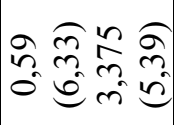 & $\begin{array}{ll} \pm & \overparen{2} \\
\approx & 0 \\
- & =\end{array}$ & $\begin{array}{ll}\square & \hat{2} \\
0 & 0 \\
0 & 0\end{array}$ & 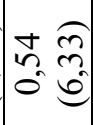 & \begin{tabular}{ll}
$\infty$ & $\widehat{2}$ \\
\hdashline & $\sigma$ \\
- & $\sigma$
\end{tabular} & $\begin{array}{ll}\infty & 0 \\
\sim & 0 \\
\sim & 0 \\
0\end{array}$ & \begin{tabular}{cc}
\multirow{2}{*}{} & $\overparen{0}$ \\
0 & - \\
1 & 1
\end{tabular} & 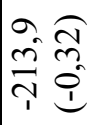 & 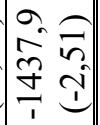 & $\begin{array}{l}\infty \\
\infty \\
n \\
0\end{array}$ & $\begin{array}{l}0 \\
\infty \\
\infty \\
0\end{array}$ \\
\hline$\frac{1}{\alpha}$ & $\underset{\Omega}{\Omega}$ & $\begin{array}{l}n \\
0 \\
0 \\
0\end{array}$ & 坣 & $\frac{\tilde{d}}{\alpha}$ & $\stackrel{\Omega}{s}$ & 象 & 只 & $\frac{\tilde{d}}{\underline{\alpha}}$ & $\underset{\sim}{\mathfrak{s}}$ & $\begin{array}{l}n \\
0 \\
0 \\
0\end{array}$ & 党 \\
\hline & & $\underset{\text { 피 }}{0}$ & & & & $\stackrel{0}{2}$ & & & & & \\
\hline
\end{tabular}




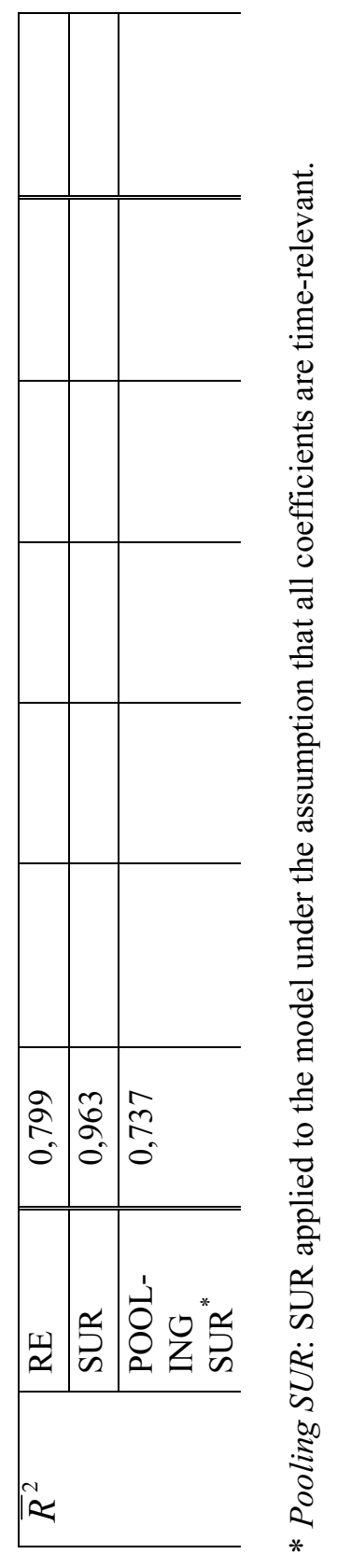




\section{References}

Amemiya, T. (1971), «The Estimation of Variances in a VarianceComponents Model», International Economic Review, Vol. 12, pp 113.

Alchian, A. and Demsetz, H., (1972), "Production Information Costs and Economic Organisation", American Economic Review, Vol. 62, pp 777-795.

Baltagi, B.H., (1995), «Econometric Analysis of Panel Data», John Wiley and Sons

Chagnanti, R. and Damanpour, F., (1991), "Institutional Ownership, Capital Structure and Firm Performance", Strategic Management Journal, Vol.12, pp 479-491.

Chamberlain, G., (1982), "Multivariate regression models for panel data", Journal of Econometrics, Vol. 18, pp 5-46

Cubbin, J. and Leech, D., (1983), "The Effect of Shareholding Dispression on the Degree of Control in British Companies: Theory and Measurement", Economic Journal, Vol. 93, pp 351-369.

Demsetz, H., (1983), "The Structure of Ownership and the Theory of the Firm", Journal of Law and Economics, Vol. 26, pp 375-390.

Drucker, P.F., (1976), "The Unseen Revolution: How Pension Fund Socialism Came to America", Heinemann.

Fama, E., (1980), "Agency Problems and the Theory of the Firm", Journal of Political Economy, Vol. 88, pp 288-307.

Feltham, G and Ohlson, J., «Valuation and Clean Surplus Accounting for Operating and Financial Activities», Contemporary Accounting Research, Vol. 11, pp 689-731.

Graves, S.B., (1988), "Institutional Owenership and Corporate R\&D in the Computer Industry", Academy of Management Journal, Vol. 31, pp 417-428

Greene, W., (1997), «Econometric Analysis», 3rd edition, Prentice-Hall.

Hansen, G.S. and Hill, C.W.L., (1991), "Are Institutional Investors Myopic? A Time-Series Study of Four Technology-Driven Industries", Strategic Management Journal, Vol. 12, pp 1-16.

Hausman, J.A. and Taylor, W.E., (1981), «Panel Data and Unobservable Individual Effects», Econometrica, Vol. 49, pp 1377-1398.

Hermalin, B.E. and Weisbach, M.S., (1987), "The Determinants of Board Composition", Rand Journal of Economics, Vol. 19, pp 589-606.

Hirschman, A.O., (1970), Exit, Voice and Loyalty: Responses to Decline in Firms, Organisations and States", Harvard University Press. 
Hock, I., (1962), «Estimation of Production Function Parameters Combining Time-Series and Cross-Section Data», Econometrica, Vol. 30, pp 3453.

Holderness, G.R. and Sheehan, D.P., (1988), "The Role of Majority Shareholders in Publicly Held Corporations", Journal of Financial Economics, Vol. 20, pp 317-346.

Holl, D.A., (1975), "Effect of Control Type on the Performance of the Firm in the U.K.", Journal of Industrial Economics, Vol. 23, pp 257-271.

Hutton, W., (1995), "The State We' re In", Jonathan Cape.

Jacquemin, A. and De Ghellinck, E., (1980), "Familial Control, Size and Performance in the Largest French Firms", European Economic Review, Vol. 13, pp 81-91.

Jensen, M. and Meckling, W., (1976), "Theory of the Firm: Management Behaviour, Agency Costs and Ownership Structure", Journal of Financial Economics, Vol. 4, pp 305-360.

Karathanassis G. and Philippas N. (1988), "Estimation of Bank Stock Price Parameters and the Variance Components Models", Applied Economics, pp.497-507.

Keenan, W. (1970), "Models of Equity Valuation: The Great Germ Bubble", Journal of Finance, pp. 243-273.

Kuh, E. and S. Mayer (1957), "How Extraneous are Extraneous Estimates", Review of Economics and Statistics pp. 380-393.

Leech, D. and Leahy, J., (1991), "Ownership Structure, Control Type Classifications and the Performance of Large British Companies", Economic Journal, Vol. 101, pp 1418-1437.

Maddala, G.S., (1971), «The Use of Variance Components in Pooling CrossSection and Time-Series Data», Econometrica, Vol. 39, pp 341-358.

Martin, K. and McConnell, J., (1990), "Corporate Performance, Corporate Takeovers and Management Turnover", Journal of Finance, Vol. 45.

McConnell, J.J. and Servaes, H., (1990), "Additional Evidence on Equity Ownership and Corporate Value", Journal of Financial Economics, Vol.27, pp 595-612.

Miller, M. and Modigliani, F., (1961), "Dividend Policy, Growth and theValuation of Shares", The Journal of Business, Vol. 34, pp 261275.

Morck, R., Shleifer, A. and Vishny, (1988), "Management Ownership and Market Valuation", Journal of Financial Economics, Vol. 20, pp 293315.

Mundlak, Y., (1963), «Estimation of Production and Behavioral Functions from a Combination of Cross-Section and Time-Series Data», in Christ, C.F. (ed.), Measurement in Economics, Stanford University Press. 
Mundlak, Y., (1978), «On the Pooling of Time-Series and Cross-Section Data», Econometrica, Vol. 46, pp 69-85.

Murali, R. and Welch, J.B., (1989), "Agents, Owners, Control and Performance", Journal of Business Finance and Accounting, Vol. 16, pp 385-398.

Ohlson, J.A., (1989) "Accounting Earnings, Book Value and Dividends: The Theory of Clean Surplus Equation (Part I)", Working Paper, Columbia University.

Ohlson, J.A., (1995), "Earnings, Book Values, and Dividends in Equity Valuation", Contemporary Accounting Research, Vol. 11, 1995, 661687.

Pound, J., (1988), "Proxy Contests and the Efficiency of Shareholder Oversight", Journal of Financial Economics, Vol. 20, pp 237-265.

Pindyck, R. and Rubinfeld, D., (1981), Econometric Models and Economic Forecasting, McGraw Hill, New York.

Radice, H.K., (1971), "Control Type, Profitability and Growth in Large Firms: An Empirical Study", Economic Journal, Vol. 8, pp 547-562.

Ramsey, J.B. "Tests for Specification Error in Classical Linear Least Squares Regression Analysis ", Journal of the Royal Statistical Society, 1969, pp. 350-371.

Scherer, R. (1980), "Industrial Market Structure and Economic Performance", R and McNally College Publishing Company.

Shleifer, A. and Vishny, R. (1986), "Large Shareholders and Corporate Control", Journal of Political Economy, Vol. 94, pp 145-148.

Short, H., (1994), "Ownership, Control, Financial Structure and the Performance of Firms", Journal of Economic Surveys, Vol. 8, pp 203-247.

Short, H. and Keasey, K., (1997), "Institutional Shareholders and Corporate Governance" in Keasey, K. and Wright, M. (eds.) "Corporate Governance: Responsibilities, Risks and Remuneration", Wiley and Sons.

Steer, P. and Cable, J., (1978), "Internal Organisation and Profit: An Empirical Analysis of Large U.K. Companies", Journal of Industrial Economics, Vol. 27, pp 13-30.

Thonet, P. and Pensgen, O., (1979), "Managerial Control and Economic Performance in West Germany", Journal of Industrial Economics, Vo. 28, pp 23-37.

Williamson (1964) "The Economics of Discretionary Behavior: Managerial Objectives in a Theory of the Firm". Prentice Hall International Editions.

Zellner A. "An Efficient Method of Estimating Seemingly Unrelated Regression and Tests for Aggregation Bias", Journal of the American Statistical Association, June (1962), pp. 348-368. 